\title{
Land use and land cover mapping and identification of misuse in the permanent preservation areas in the Tailândia Municipality - PA
}

\author{
Mapeamento do uso e cobertura da terra e identificação de uso \\ indevido em áreas de preservação permanente no Município de \\ Tailândia - PA
}

Rosana Sumiya Gurgel $^{1 *}$; Paulo Roberto Silva Farias ${ }^{2}$; Sandro Nunes de Oliveira ${ }^{3}$

\begin{abstract}
The objective of this study is to expand the mapping of land use and land cover, as well as of the permanent preservation areas (PPAs), and identify land misuse areas in the PPAs in the Tailândia municipality in the state of Pará, which is part of the Amazon biome. Remote sensing techniques and geographic information systems (GIS) were used to achieve these goals. Mapping and classification for the year 2012 were made by visual interpretation of images obtained from the RapidEye satellite, which has a $5 \mathrm{~m}$ spatial resolution. In this work, we identified nine classes of land use and land cover. From the hydrography vectors it was possible to determinate the Permanent Preservation Areas of the bodies of water according to the environmental legislation. Analysis of misuse in the PPAs was made by crossingchecking the land use and land cover data with that of the PPAs. The results show that $53 \%$ of the municipality $\left(2,347.64 \mathrm{~km}^{2}\right)$ is occupied by human activities. Livestock farming is the activity that has most increased the use of area (30\%), followed by altered vegetation $(14.6 \%)$ and palm oil $(7.2 \%)$. The PPAs have a high percentage of misuse (47.12\%), with livestock being the largest contributor, occupying $26.65 \%$ of the PPAs, followed by altered vegetation (12.64\%) and palm oil (4.29\%). Therefore, the main objective in Tailândia is to reconcile economic activity with sustainable development. It is important to emphasize the partnerships between the government, research institutions, regulatory agencies, states departments and local communities, else it would be impossible to monitor or control an area as vast as the Amazon.
\end{abstract}

Key words: Amazon deforestation. Remote sensing. Land use and land cover. Misuse in the PPAs.

\section{Resumo}

O presente trabalho tem como objetivo elaborar o mapeamento de uso e cobertura da terra bem como mapear as Áreas de Preservação Permanente (APPs) e identificar as atividades infratoras em APPs no município de Tailândia no estado do Pará, que faz parte do bioma da Amazônia. Para este fim, técnicas de sensoriamento remoto e Sistema de Informação Geográfica foram utilizadas. O mapeamento e a classificação foram realizados por interpretação visual das imagens de satélite RapidEye com $5 \mathrm{~m}$ de resolução espacial para o ano de 2012. Foram identificadas nove classes de uso e cobertura da terra. A partir dos vetores de hidrografia foi possível determinar as Áreas de Preservação Permanente dos corpos d'agua de acordo com a legislação ambiental. A análise do uso indevido em APPs foi feito a partir do cruzamento de dados do uso e cobertura da terra com as APPs. Segundo os dados obtidos $53 \%$ do município $\left(2.347,64 \mathrm{~km}^{2}\right)$ são ocupados por atividades antrópicas. A pastagem é a atividade que possui maior área de uso (30\%), seguido pela vegetação alterada $(14,6 \%)$ e dendê $(7,2 \%)$. As APPs

\footnotetext{
${ }^{1}$ Doutorado em Agronomia, Universidade Federal Rural da Amazônia, UFRA, Belém, PA, Brasil. E-mail: rsumiya@gmail.com

${ }^{2}$ Prof. Associado IV, Universidade Federal Rural da Amazônia, UFRA, Belém, PA, Brasil. E-mail: paulo.farias@ufra.edu.br

3 Prof., Instituto Federal de Brasília, IFB, Campus Gama, Gama, DF, Brasil. E-mail: sandro.oliveira@ifb.edu.br

* Author for correspondence
}

Received: May 17, 2016 - Approved: Dec. 17, 2016 
possuem uma alta porcentagem de uso indevido (47,12\%), sendo que a pastagem é a maior infratora, ocupando $26,65 \%$ das APPs, seguida pela vegetação alterada $(12,64 \%)$ e dendê $(4,29 \%)$. Portanto o principal desafio do município é conciliar a atividade econômica e o desenvolvimento sustentável, sendo importante salientar que são necessárias as parcerias entre o Estado, as instituições de pesquisas, órgãos fiscalizadores, secretarias estaduais e comunidades locais, pois sem essas parcerias seria impossível fiscalizar ou controlar uma área tão imensa quanto o da Amazônia Legal.

Palavras-chave: Desmatamento da Amazônia. Sensoriamento remoto. Uso e cobertura da terra. Uso indevido em APPs.

\section{Introduction}

The occupation of the Brazilian Amazon dates back to the Portuguese colonization, and includes the period of the Amazon rubber boom (18791912), the period of the military government (19641985), which sought to integrate the region with the rest of the country, and the more recent expansion of agriculture in the region (PRATES; BACHA, 2011). Deforestation in the Amazon intensified in the 1980s due to tax subsidies granted by the federal government to attract private capital to the Amazon. These incentives were particularly to implement large agricultural projects supported by fiscal incentives in southern Pará and northern Mato Grosso, and road construction, such as the PA70, the Belém-Brasília highway (BR-153), and the Trans-Amazonian highway (BR-230), facilitating further deforestation in the central portion of the Amazon forest (FEARNSIDE, 2006; PRATES; BACHA, 2011).

Wildfires, selective logging, rural settlements, and expansion of agricultural activities have resulted in significant destruction of forests, thus increasing deforestation in the region (FEARNSIDE, 2006; TAVARES, 2011). The major impacts of this occupation process have been the loss of biodiversity, soil impoverishment, climate change, alteration of the hydrological regime, and overall environmental degradation (FEARNSIDE, 2010).

The regions of the Amazon that have undergone greatly expanded land occupation have become known as the "Arc of Deforestation." This region is where plantations have encroached towards the forest, where the highest rates of deforestation in the Amazon are found, and includes western and northwestern Maranhão; eastern, southern, and partially western Pará; western and northern Tocantins; eastern, central-western, and northern Mato Grosso, the entire state of Rondônia and Acre, and southern Amazonas (IPAM, 2012). The region has been increasingly occupied due to the construction of federal, state, and local highways, which have moved towards the hinterland of the Amazon over time (TAVARES, 2011; FEARNSIDE, 2010). In addition to the major road networks, other roads have been rapidly built in the Amazon, without any supervision or government incentives. Commonly, these new access roads have been built to facilitate logging, but they also bring new colonization, forest fragmentation, ecological degradation, and increasing wildfires (BARBER et al., 2014).

Brazilian environmental legislation, especially Brazil's Forest Code (BRASIL, 1965, 2012), has greatly influenced land occupation (ALARCON et al., 2015; OLIVEIRA, 2015a). This federal law determines the demarcation of PPAs and legal reserves (LRs) in all rural properties. The LR corresponds to $80 \%$ of each rural property in the Amazon biome, $35 \%$ in the Cerrado located in the Legal Amazon, 20\% in general fields located in the Legal Amazon, and 20\% in the rest of the country.

Brazil's Forest Code of 1965 states that PPAs are protected areas, where it is prohibited to build, grow, or exploit by economic activity, whether covered or not by native vegetation. The environmental function of the PPAs is to preserve water resources, landscape, geological stability and biodiversity, 
facilitate gene flow of fauna and flora, protect the soil, and ensure the well-being of human populations. However, the Forest Code of 1965 did not regulate land occupation, which was only regulated by the National Council for the Environment - CONAMA resolutions 302/2002 and 303/2002. Brazil's new Forest Code, Law no. 12651/12, has maintained the concept of PPAs established in the Forest Code of 1965, although some changes have been made. Concerning LRs, the required percentages for each biome were maintained, although the computation of PPAs to calculate the LR in rural properties, which was previously allowed only for small properties in specific cases, is currently subject to greater flexibility; it may include properties of any size, since it does not involve deforestation of new areas (OLIVEIRA, 2015b).

The scientific community advocates that compensation for deficit in an LR should be provided in areas closer to the properties, within the same ecosystem, preferably in the same watershed or river basin. However, the new Forest Code allows that the compensation may be realized within the same biome, which does not ensure the ecological equivalence in structure, composition and function (SBPC; ABC, 2012). Felfili et al. (2004) demonstrated this aspect with respect to the Cerrado biome, when they evaluated the vegetation density and variety of species in three national parks of the biome, and verified that the greater the distance between the remaining vegetation without wildlife corridors, the more significant the loss of variety of species.

Another controversial proposal is to suspend or forgive environmental debts of "small" properties (ranging from 20 ha in southern Brazil to 440 ha in the Amazon) due to illegal deforestation prior to July 22, 2008. Under this new rule, $90 \%$ of rural properties may have their environmental debts suspended (SOARES FILHO et al., 2014).

In view of the dynamics of change in land use, in addition to the changes that the environmental legislation has recently undergone, mapping and monitoring the Earth's surface by remote sensing are thus of great importance. Remote sensing and geoprocessing techniques have been widely used to obtain spatial and temporal data on changes in land use, and are important tools for land management and environmental planning, both at the regional and municipal level (CATELANI; BATISTA, 2007). These technologies include mathematical and computational techniques for spatial data management, permitting spatialization and superior visualization, analysis, and interpretation of the collected data (SARAIVA et al., 2010).

Remote sensing is an important tool to significantly reduce legal loopholes related to the application of legislation, since it enables the integration of cartographic and tabular data. This allows environmental analysis to establish a causeeffect relationship (REIS et al., 2009), and is used mainly to support the investigation of adequacy of land use in PPAs (AULICINO et al., 2000).

Remote sensing at an orbital level, coupled with geoprocessing techniques, allows the simultaneous management of several data sets of the terrestrial surface, and the acquisition of results at different scales, allowing the identification of land use, and supporting the monitoring and controlling of deforestation (REIS et al., 2009).

The cartographic scale mainly used in most of the municipalities in the Amazon is 1:100,000. However, this scale does not allow road and hydrographic networks, land use and land cover, and other geographic features of the municipality to be defined in detail, which are fundamental to the definition of PPAs. Further, we have not mentioned "cartographic emptiness," although about $35 \%$ of the Amazon is devoid of geographic data (CENSIPAM, 2016).

In order to provide a more accurate database, that database should be scaled to detect small-scale deforestation $(<1 \mathrm{ha})$, which is generally located in settlements and invasion areas that cannot be 
detected at the 1:100,000 scale (SOUZA JÚNIOR et al., 2013). To solve this problem, satellite images with different spatial and spectral resolutions have been used, according to their applications (GURGEL et al., 2011). High-resolution images (between 0.50 $\mathrm{cm}$ and $5 \mathrm{~m}$ ) are generally used to map land use and land cover in urban planning, rural land register, and environmental mapping, allowing greater detailing of detected features. Similarly, this study aims to map the municipality of Tailândia at the 1:20,000 scale, to identify the spatialization of several types of land use and land cover, to analyze the context and spatial distribution of PPAs, and to identify misuse areas in the PPAs.

\section{Materials and Methods}

\section{Study area}

The study area is the municipality of Tailândia, located in northeastern Pará, between the geographic coordinates $02^{\circ} 36^{\prime}$ and $03^{\circ} 24^{\prime}$ south latitude, and $48^{\circ} 58^{\prime}$ and $48^{\circ} 33^{\prime}$ 'west longitude. It is bounded by Acará to the north, Tomé-Açú to the east, Ipixuna do Pará to the south, and Moju to the west. The municipality is part of the Integrated Area of Lower Tocantins, including 10 other municipalities. The 11 municipalities comprising the Lower Tocantins are: Abaetetuba, Acará, Baião, Barcarena, Cametá, Igarapé-Miri, Limoeiro do Ajuru, Mocajuba, Moju, Oeiras do Pará, and Tailândia (Figure 1). Tailândia has an area of $4,430 \mathrm{~km}^{2}$ and an estimated population of 97,161 inhabitants in 2015 (IBGE, 2015).

Figure 1. Location map of Tailândia. Clockwise from top right: A. Brazil; B. Para State; and C. Tailândia.

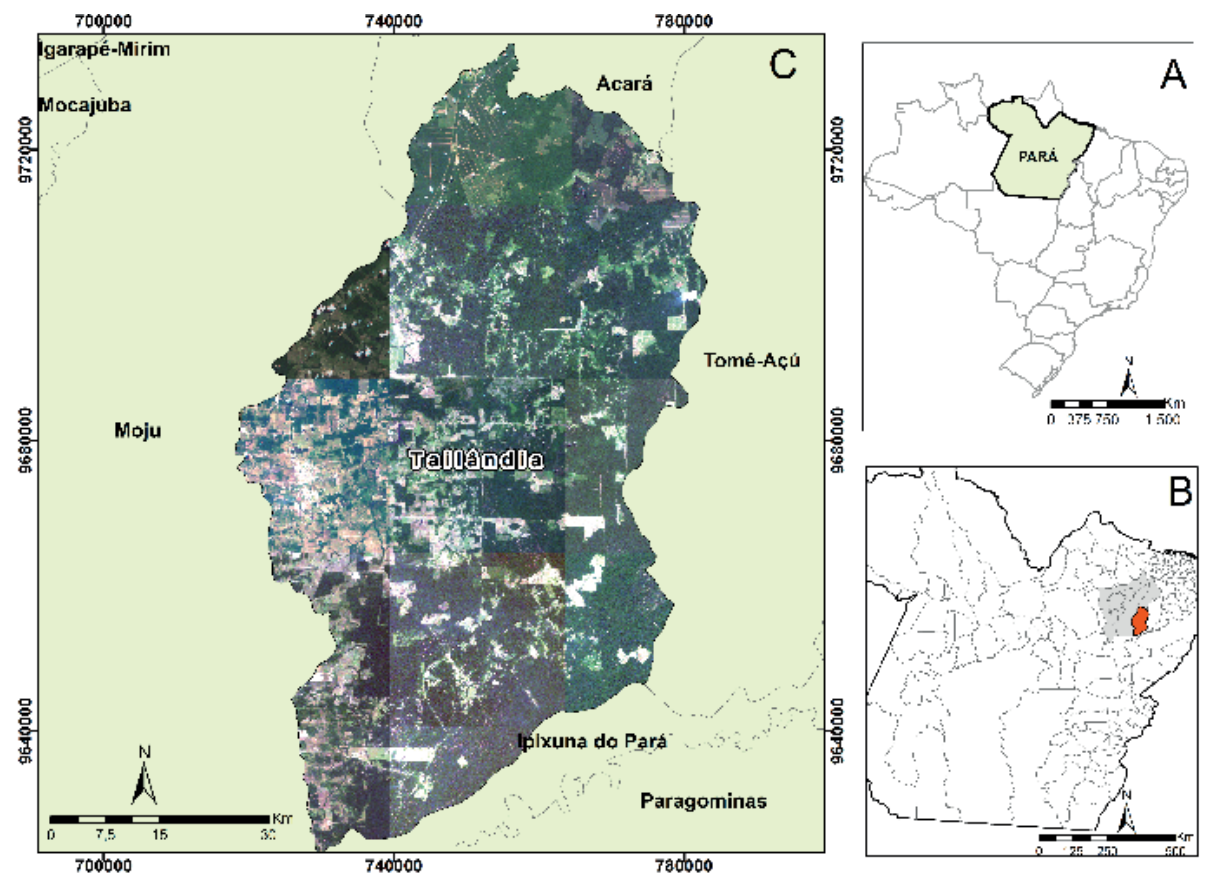

The predominant soils in the region are: (1) Yellow Latosols in solid ground areas with a flat and smoothly undulating relief, (2) plinthosols in floodplain areas, (3) gleysols in lowland floodplain areas, which are soils under the influence of groundwater, permanently or periodically saturated with water, and (4) fluvic neosols in alluvial plains, limiting agricultural use due to periodic flooding (RODRIGUES et al., 2005). 
The geomorphology of the region consists of alluvial plains and the lower Amazon basin. It does not present significant variation in elevation, and is predominantly flat, with a smoothly undulating relief. The elevation is around $35 \mathrm{~m}$, with a maximum of $96 \mathrm{~m}$ to the south (RODRIGUES et al., 2005; IDESP-PA, 2014).

The vegetation covering most of the municipality is semi-evergreen equatorial forest, which is characterized by varied phytophysiognomy and structure, and includes several species of economic value. Várzea equatorial forest is found in areas near the banks of the Acará River, with species adapted to seasonal water inundation due to overflow of the watercourses, mainly during periods of heavy rainfall. Shrubby Campinarana vegetation, along with palms and grasses, occur in waterlogged sandy areas (RODRIGUES et al., 2005; IDESP, 2014).

According to the climate classification of Strahler (1951), the climate is equatorial 1b, with semi-drying for one to two months. The mean rainfall index ranges from 2000 to $3000 \mathrm{~mm} / \mathrm{yr}$. Despite the high annual rainfall, there is a shortage in Tailândia due to the low rainfall of $341 \mathrm{~mm}$ in the driest months, from June to August (RODRIGUES et al., 2005).

\section{Historical and socioeconomic aspects}

The history of occupation in the municipality, since Portuguese colonization, is mainly based on forest exploitation, especially logging and livestock activity, facilitated by the navigability of the Acará River (IDESP, 2014). The municipality of Tailândia previously belonged to the municipality of Acará, which originated during the expansion of Portuguese exploitation into the hinterland of the Province (IBGE, 2015). In the 1970s, when the highway PA150, which traverses the state of Pará from north to south, was built, land conflicts were triggered between farmers, land grabbers, and squatters along the roadside (LOUREIRO; PINTO, 2005). Because the violence of these conflicts intensified, the state government intervened in the region, thus initiating the registration of settlers, demarcation of vacant lands, and the distribution of lots between kilometers 51 and 183 of PA-150, totaling 158,400 ha. However, Tailândia only achieved the political and administrative status of a municipality in May 1988 (IBGE, 2015).

Due to strong anthropization, Tailândia was one of the most deforested municipalities in the Lower Tocantins, according to satellite monitoring data of the Amazon forest-PRODES, provided by the Brazilian Institute for Space Research (INPE, 2014). Since 2000 until 2014, the area of Tailândia that had already been deforested by logging was 2,236.90 $\mathrm{km}^{2}$, or $50 \%$ of the municipality, following Moju and Acará.

Logging, and mainly illegal logging, was the predominant economic activity in Tailândia until 2008. Then, in 2008, the federal government determined that the state would intervene in the region. It was the first municipality in which socalled operation "Fire Bow" was enforced, and which levied, fined, confiscated illegally harvested timber, and destroyed charcoal kilns. Tailândia was entered on the List of Priority Municipalities of the Ministry of Environment (MMA Ordinance no. 28/2008), and faced economic stagnation and a rising unemployment rate (PENTEADO, 2010).

In 2013, Tailândia was taken off the List of Priority Municipalities (MMA Ordinance no. 412/2013). The main requirements to be taken off the list are: (1) rural properties registered in the Rural Environmental Registry (CAR) must comprise $80 \%$ of the municipality; and (2) deforestation in 2012 was $\leq 40 \mathrm{~km}^{2}$. In this way, Tailândia became a member of a category of municipalities with deforestation monitored and under control, in that the municipality has the right to receive several fiscal incentives and access to finance, as well as public policies for land development and land planning (IMAZON, 2014).

Another important economic highlight in the municipality is that AGROPALMA, one of the 
largest producers of palm oil in the region, grew extensive oil palm fields. The oil is widely used in the food and chemical industries. Recently, palm oil production has increased because it has become integrated into the biofuel energy matrix of Brazil's Biodiesel Production and Use Program - PNPB (NAHUM; MALCHER, 2012). However, the Agroecological Zoning for Oil Palm has forbidden new fields to grow oil palm (EMBRAPA SOLOS, 2010), that is, only fields plowed before 2008 may grow oil palm, according to data provided by the PRODES/INPE.

\section{RapidEye imagery}

The RapidEye satellite consists of a constellation of five multispectral, identical microsatellites synchronously positioned in orbit with the sun, and with the satellites equally spaced from each other. This configuration allows greater efficiency for repetitive collection of images of the Earth surface with high data accuracy, completing 15 laps around the planet daily. RapidEye sensors can collect images of the Earth surface over 77-km in width and up to 1,500-km in length (BLACKBRIDGE, 2015). RapidEye offers highly enhanced capabilities to produce a set of images for any point on the Earth in a short time. It can revisit the same place within 24 hours, making it useful mainly for monitoring the dynamics of land use, which requires faster data update (BLACKBRIDGE, 2015).

To map the municipality of Tailândia, this study used 16 previously processed and orthorectified RapidEye satellite images from 2012, acquired and assigned by the Ministry of Environment - MMA. The images have a $5 \mathrm{~m}$ spatial resolution, i.e., each pixel represents a terrain of $0.0025 \mathrm{ha}^{2}$, with compatible detail accuracy at the 1:20,000 scale. RapidEye has sensors with five spectral bands: blue (440-510 nm), green (520-590 nm), red (630-685 $\mathrm{nm})$, red-edge (690-730 nm), which are specific for monitoring the photosynthetic activity of vegetation, and near infrared (760-850 nm) (BLACKBRIDGE, 2015).

\section{Spot-5 Image}

We also used eight images from the Spot-5 satellite from 2008, which were provided by the Secretariat of Environment and Sustainability (SEMAS-PA). Spot-5 images have high spatial resolution of $2.5 \mathrm{~m}$, compatible with RapidEye, and are $60-\mathrm{km}$ in width (ENGESAT, 2002).

As the RapidEye images are available from 2012, land cover images from RapidEye were overlapped with the Spot-5 images from 2008, making it possible to identify pasture areas from 2008 that were later used to grow oil palm.

\section{Land use and land cover mapping}

Data may be extracted from satellite images using two techniques. The first technique is the automatic classification of images, using specific algorithms, aimed at mapping land use and land cover with different spectral characteristics (AMARAL et al., 2009). The second technique is manual mapping and classification of satellite images by specialists who interpret images based on data obtained through field research and historical context. The basic properties of the satellite image that allow identification of several types of land use are differences in texture, color, shape, size, density, structure, and context relations of the images (SOUZA et al., 2011; GURGEL et al., 2013).

While automatic classification optimizes and accelerates image processing, modeling texture and structure by manual classification has not achieved satisfactory results (MENESES; SANO, 2012), because specialists can confuse vigorous vegetation of gallery forest with vigorous vegetation of reforestation, since both are spectrally similar (MENESES; SANO, 2012). Similarly, specialists can confuse areas of sparse or deforested vegetation with urban areas (GONÇALVES et al., 2008). In other words, these results do not provide reliable, good quality maps, demanding time-consuming editing after classification (VASCONCELOS, NOVO, 2004). 
After mapping using a screen, the topological correction and classification of the vector data of identified polygons were performed. The classes of land use used in the classification are plantations, pasture, oil palm, native vegetation, altered vegetation, logging, urbanized area, artificial reservoir, and body of water. In this manner, all the geoenvironmental parameters of the municipality were incorporated using GIS to support the environmental management of the region.

\section{Misuse in PPAs}

The PPAs of all water bodies and their artificial springs and reservoirs were identified in the municipality of Tailândia. This mapping was defined according to the new Forest Code (Law no. $12561 / 2012$ ), whereby water bodies up to $10 \mathrm{~m}$ wide are designated PPAs of $30 \mathrm{~m}$; rivers from 10 to $50 \mathrm{~m}$ wide are designated PPAs of $50 \mathrm{~m}$; rivers from 50 to $200 \mathrm{~m}$ wide are designated PPAs of $100 \mathrm{~m}$; and PPAs of $50 \mathrm{~m}$ are designated around springs. In respect of artificial reservoirs, although the new Forest Code has been enacted, the CONAMA resolution no. $302 / 2002$ is still in force as new regulation cannot retroactively prejudice and harm the environmental rights acquired, without due compensation (AGU, 2013). Thus, in the case of artificial reservoirs up to 20 ha in rural areas, the CONAMA resolution no. 302/2002 designates PPAs of $15 \mathrm{~m}$, while PPAs of $100 \mathrm{~m}$ are designated in the case of artificial reservoirs over 20 ha in rural areas.

The drainages were mapped manually by visual interpretation of RapidEye satellite images and vectorization on screen. To help visualize bodies of water that are difficult to identify, drainages were extracted from Shuttle Radar Topography Mission (SRTM) data, which is a Digital Terrain Model (DTM) that represents the relief in three spatial dimensions: latitude, longitude, and altitude (x, y, z) (CARVALHO; BAYER, 2008). The drainages generated from SRTM were overlain onto the manually extracted images of the watercourses by digitizing the vector data from the RapidEye satellite image.

The identification of areas of misuse in the PPAs was performed by comparing the land use and land cover data with that of the PPAs, which allowed the areas of misuse to be delimited and their spatial distribution in Tailândia to be determined, as well as identify which activities found in the PPAs contravene the new Forest Code.

\section{Results and Discussion}

\section{Land use and land cover mapping}

Figure 2 shows land use and land cover mapping for Tailândia, based on the visual interpretation of RapidEye images from 2012.

Table 1 shows that the $4,430 \mathrm{~km}^{2}$ of the municipality was occupied as follows: $47 \%$ with natural vegetation, $30 \%$ with pasture, $14.6 \%$ with altered vegetation, $7.2 \%$ with oil palm, $1 \%$ with other uses, $0.1 \%$ with logging, and $0.1 \%$ with artificial reservoirs. Thus, areas with some anthropically imposed land use totaled $53 \%$ of the municipality.

The land use and land cover mapping in Tailândia shows that most anthropogenic activities are in the central portion of the municipality, bordering the main highway PA-256, which intersects PA-150, a major highway in the state of Pará that connects northeastern Pará to the southeast portion of the state. Highways are a major cause of exponentially increased deforestation in the Amazon (FERREIRA et al., 2005), that is, deforestation assumes widespread proportions near highways (FERREIRA, 2001). According to Nepstad et al. (2001), three quarters of the deforestation between 1978 and 1994 occurred within a 100-km wide strip along BR-010 (Belém-Brasília), BR-364 (CuiabáPorto Velho), and PA-150. 
Figure 2. Land use and land cover mapping.

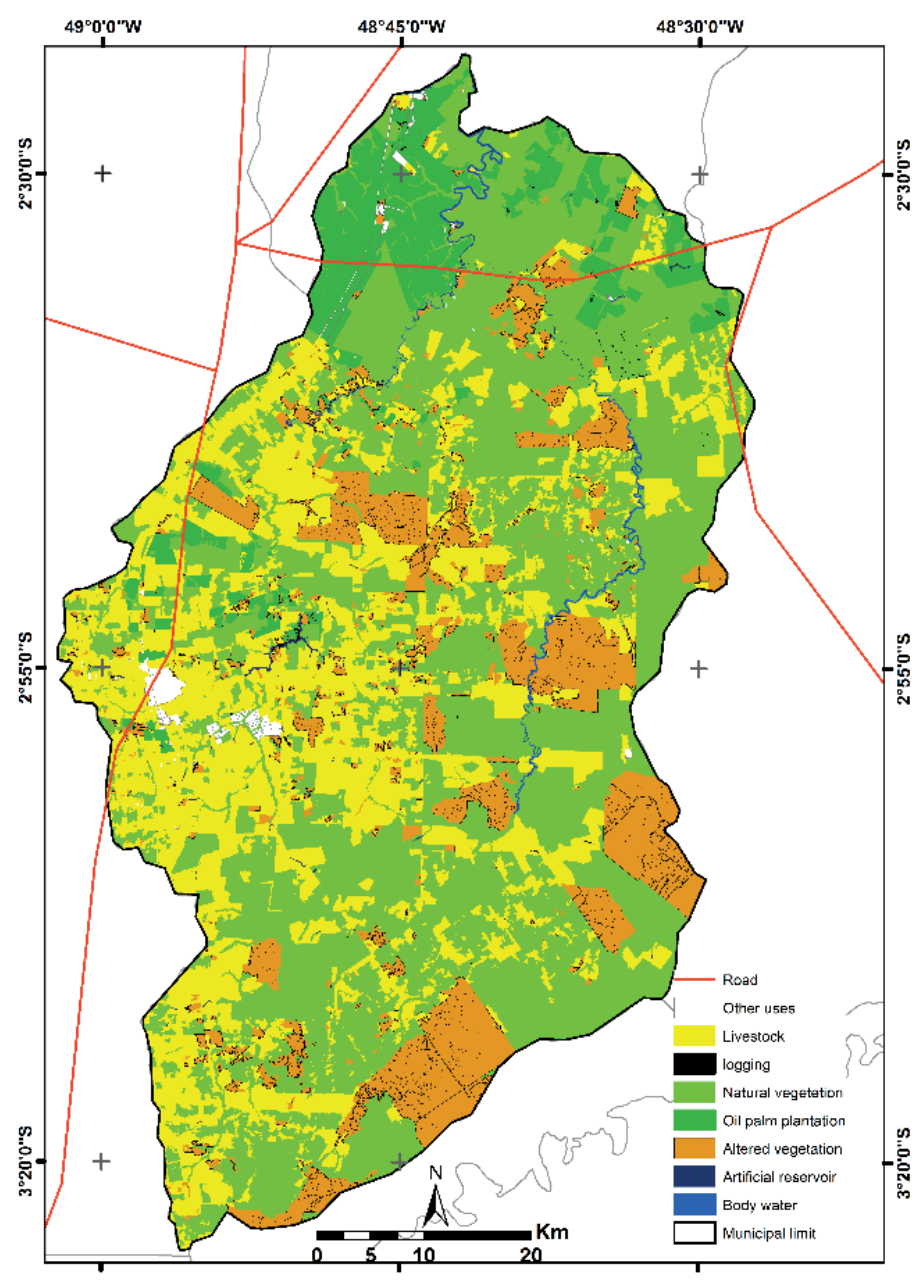

Pastoral activity occupies most anthropic land use, corresponding to $1,329.86 \mathrm{~km}^{2}$ of the area of the municipality. Several studies, such as Watrin et al. (2007) in Paragominas, Barbosa Júnior (2012) in Bonito, Almeida and Vieira (2014) in Moju, and Adami et al. (2015) in the state of Pará, included livestock in the Amazon. Fearnside (2001) estimated that $80 \%$ of the deforested areas in the Amazon were pasture or secondary vegetation in areas of degraded and/or abandoned pasture.

The natural vegetation covers 2,083.36 $\mathrm{km}^{2}$ (47\%), mainly in the hinterland of the municipality, although it is giving way gradually to logging, covering only $0.1 \%$ of the municipality. However, it is worth noting that from the 4,319 polygons mapped for logging activity, 2,998 polygons were smaller than 0.09 ha, the minimum area detectable by a satellite with a $30 \mathrm{~m}$ spatial resolution. Thus, $69 \%$ of logging occurs in areas smaller than 0.09 ha, which are not detected by satellites commonly used to monitor deforestation in the Legal Amazon, due to their spatial resolution of $30 \mathrm{~m}$. Clearly, it is important to use high-resolution satellites, such as RapidEye, which allows areas of 0.0025 ha to be resolved and displayed, for a more effective monitoring and controlling. 
Table 1. Land use and land cover classification.

\begin{tabular}{lcc}
\hline \multicolumn{1}{c}{ Land use classification } & $\begin{array}{c}\text { Area } \\
\left(\mathbf{k m}^{\mathbf{2}}\right)\end{array}$ & $\begin{array}{c}\text { Land use } \\
\mathbf{( \% )}\end{array}$ \\
\hline Livestock & $1,329.86$ & 30.00 \\
Altered vegetation & 646.28 & 14.60 \\
Oil palm & 317.39 & 7.20 \\
Other uses & 43.00 & 1.00 \\
Artificial reservoirs & 5.11 & 0.10 \\
Logging & 6.00 & 0.10 \\
Total land use & $2,344.70$ & 53.00 \\
Natural vegetation & $2,083.36$ & 47.00 \\
Municipality area & $\mathbf{4 , 4 3 0 \mathbf { ~ k m } ^ { \mathbf { 2 } }}$ \\
\hline
\end{tabular}

Features corresponding to arable areas, urbanized areas, and unknown uses represent a small percentage, totaling $1 \%$ of the municipality, and are classified as other uses. Tailândia is mostly rural, its economy is based on logging activity, and therefore, the urban and arable areas do not cover much of the municipality.

In respect of artificial reservoirs, 93 polygons of different sizes were mapped, all of which are located in pastures, mostly to supply water to livestock or the properties generally. The artificial reservoirs have a mean area of 5.5 ha, whereas the largest reservoir measures 192.93 ha, and the smallest reservoir measures 0.03 ha.

The mapped areas of oil palm plantations, mainly in the northwest portion of the municipality, are consolidated areas where cultivation of the crop has occurred for about 30 years (AGROPALMA, 2014). According to Homma and Vieira (2012), the quadrilateral area bounded by Santo Antônio do Tauá and Igrapé-Açu in the north and Paragominas and Tailândia in the south shows areas of continuous monocultures of oil palm trees, which will eventually replace the current pastures and abandoned fields.

In Tailândia, it was possible to recognize the conversion of use from pasture into oil palm plantations. From 2008 to 2012, about 31 ha of pasture were converted into oil palm trees, which covers $317.39 \mathrm{~km}^{2}(7.2 \%)$ of the municipality. The converted areas are located mostly in the western part of the municipality. The conversion from pastures into oil palm plantation happens because the crop is valued in the national and international market, since palm oil is widely used in the food industry throughout the world. Palm oil is also valued as a possible biofuel, and may possibly participate in the carbon sequestration market as a forest area (BECKER, 2010). In addition to being a profitable crop, it also has a low production cost compared to soybeans. It produces ten times more oil per hectare than soybeans, and its life span is 25 years (BECKER, 2010).

However, just as any monoculture has some risks such as pests and diseases that can decimate a whole production, fatal yellowing is a major phytosanitary problem of unknown etiology for oil palm, besides the risks associated with the socio-environmental impacts of oil palm plantations (LIMA, 2011; HOMMA; VIEIRA, 2012). The reduction of environmental risks depends on compliance with the relevant legislation concerning the maintenance and recovery of the LR and PPAs, no deforestation of new areas, and emergence of pests and diseases (HOMMA; VIEIRA, 2012).

\section{Misuse in PPAs}

The PPAs in Tailândia occupy $182.95 \mathrm{~km}^{2}$, corresponding to $4.13 \%$ of the municipality (Table 2). Misuse in the PPAs is concentrated in the central 
portion of the municipality, where most pasture areas are located (Figure 3). The main offending activity responsible for the highest percentage of misuse in PPAs is livestock (26.65\%), altered vegetation (12.64\%), oil palm plantations $(4.29 \%)$, and artificial reservoirs (2.79\%).

Therefore, $47.12 \%$ of the total area of PPAs in Tailândia is occupied by some type of anthropic activity. Although most anthropic land use is in the central portion of the municipality, it is possible to observe that misuse in PPAs has occurred in branches of practically every body of water. Misuse in PPAs has continued even after environmental laws came into force. This was also verified by Almeida and Vieira (2014) in the municipality of Moju. According to the latter authors, it is worrisome, because the new Forest Code does not guarantee the recovery of these areas, thus favoring not only erosion, but also affecting subsurface water flow. Altered vegetation also covers a significant area of the PPAs. These however, have a secondary vegetation that could play an important role in the recovery of the PPAs, if isolated from disturbances (ALMEIDA; VIEIRA, 2014).

Table 2. Misuse in PPAs.

\begin{tabular}{lcc}
\hline \multicolumn{1}{c}{ Land use classification } & Area $\left.\mathbf{( k m}^{\mathbf{2}}\right)$ & Use in PPAs (\%) \\
\hline Livestock & 48.75 & 26.65 \\
Altered vegetation & 23.12 & 12.64 \\
Oil palm & 7.85 & 4.29 \\
Other uses & 1.15 & 0.63 \\
Artificial reservoirs & 5.11 & 2.79 \\
Logging & 0.22 & 0.12 \\
Total land use in PPAs & 86.20 & 47.12 \\
\hline Total area of PPAs & \multicolumn{3}{c}{$\mathbf{1 8 2 . 9 5} \mathbf{~ k m}^{\mathbf{2}}$} \\
\hline Area of PPAs in the municipality & $\mathbf{4 . 1 3 \%}$ \\
\hline
\end{tabular}

Oil palm plantations have also been a cause for concern, because they occupy 785 ha, representing $4.29 \%$ of PPAs in Tailândia, and their expansion is driven by commercial value. This crop has long been considered economically and environmentally beneficial (HOMMA et al., 2000). However, growing large areas of the same crop does not contribute to biodiversity conservation (LEES; VIEIRA, 2013). According to Homma and Vieira (2012), the increasing growth of oil palm may negatively affect the regional ecosystem, thus greater control is needed at the production center of biodiesel, to avoid the expansion of oil palm into the PPAs.
In Tailândia, $82 \%$ of bodies of water are up to 10 $\mathrm{m}$ wide (designated PPAs of $30 \mathrm{~m}$ ), $7 \%$ are between 10 to $50 \mathrm{~m}$ (designated PPAs of $50 \mathrm{~m}$ ), and $11 \%$ are between 50 to $200 \mathrm{~m}$ (designated PPAs of 100 $\mathrm{m})$. Considering that irregular activities occupy $47.12 \%$ of PPAs, most bodies of water affected by anthropic activity are small bodies of water, which are more susceptible to siltation. Misuse in PPAs generally results in the removal of riparian forest buffers, causing siltation in rivers, reducing the water flow, and consequently, causing great socioenvironmental damage. 
Figure 3. Map of misuse in PPAs.

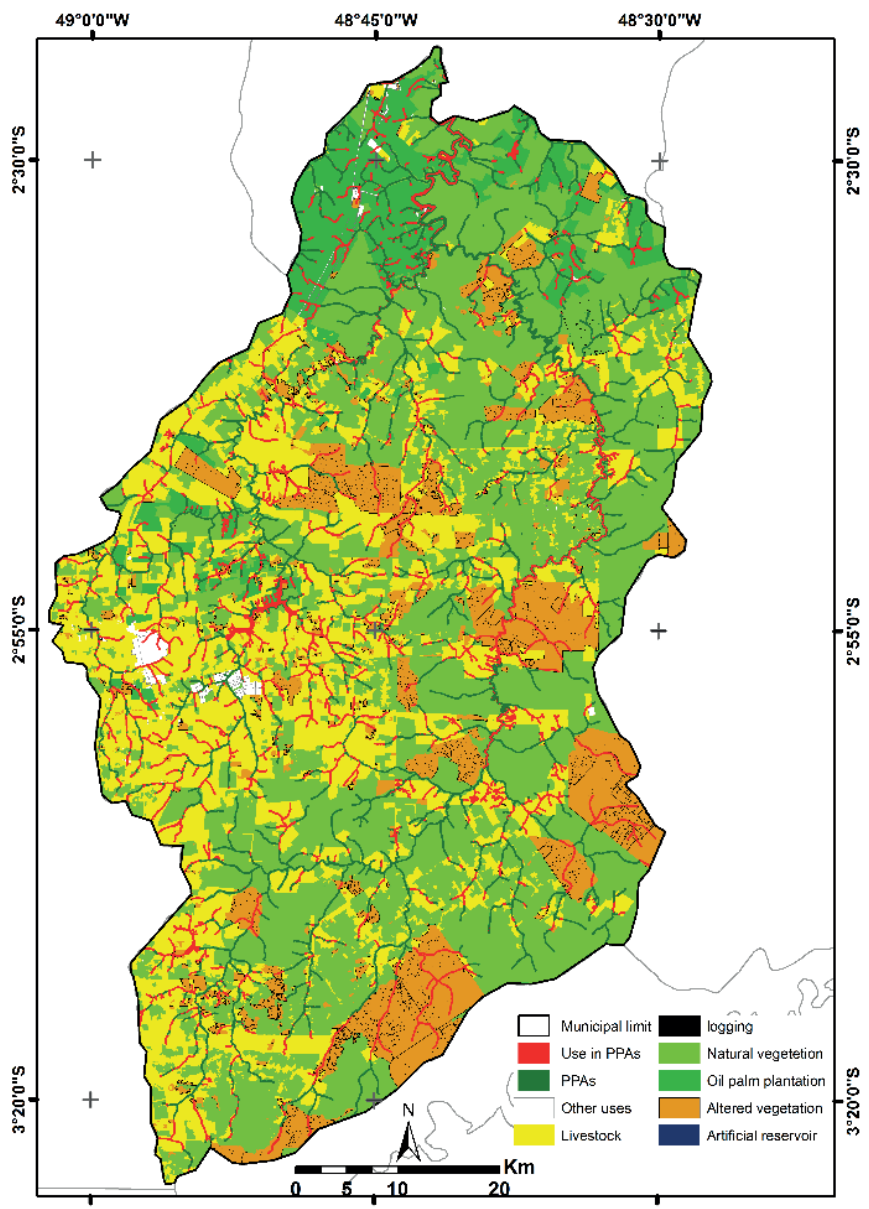

Another important observation is that no PPAs have been found around artificial reservoirs mapped in Tailândia, as required under the Forest Code. Since all reservoirs had already existed prior to the new Forest Code of 2012, PPAs should surround the reservoirs. Another aspect that was difficult to access is whether all the artificial reservoirs have environmental licensing, as required by law.

The changes introduced in the new Forest Code are a major issue concerning PPAs. Soares Filho et al. (2014) estimated that the environmental liability the new Forest Code introduced in Brazil was 21 million hectares, $22 \%$ in PPAs along riverbanks and $78 \%$ in LRs. This represents a decrease of $58 \%$ compared to that previously estimated under the former Forest Code.
PPAs have been affected by anthropic activity, suffering disruption and degradation (ALMEIDA; VIERA, 2014). The process of land use and occupation is strongly associated with social, economic, and cultural practices adopted by farmers (VIEIRA et al., 2008), which change constantly depending on market demands, such as soybean farming and beef exporting. These more volatile activities are added to the mix of traditional practices such as logging, speculative investment in real estate, and land tenure (FEARNSIDE, 2010).

Another controversial proposal concerning the PPAs is to suspend or forgive environmental debts of illegal deforestation incurred prior to July 22, 2008. Illegal deforestation, however, has violated the law since 1998. MPV no. 1605-30 of 
1998 determines that PPAs may be completely or partially removed only when necessary to execute works, plans, activities or projects of public utility or social interest, and the environmental licensing is administered by the competent environmental agency. Therefore, society has already been aware of all the limitations and prohibitions imposed by the environmental legislation between 1998 and 2008. Those who illegally deforested after 1998 did so in the knowledge that they were acting contrary to the current legislation (TAGLIALEGNA, 2011).

\section{Conclusions}

Mapping using images from the RapidEye satellite at the 1:20,000 scale allowed acquisition of detailed land use and land cover data, mainly of logging features that occur in very small areas, which makes deforestation in the region difficult to monitor and control. This study used this method to identify, quantify, and determine their geographical location.

Detailed mapping of land use and land cover allowed spatial analysis of PPAs, in order to identify how PPAs are distributed in the municipality, especially PPAs around water bodies. In this manner, areas of misuse in PPAs and major infringing anthropic activities were identified.

The results of this study are of great importance given the quantity and quality of the data, especially the level of spatial detail, which allows extraction of data for a more comprehensive understanding. In so doing, this study has mainly provided the municipality of Tailândia, in the state of Pará, with a detailed analysis of land use and land cover, and has highlighted the environmental condition of PPAs. This provides the secretariat of environment with the data that can assist in the environmental management and development of projects to enable recovery of the PPAs.

Since cooperation is more effective in combating illegal deforestation, it is essential that society participates in environmental recovery projects in order to achieve success. The government should support the community, since the preservation of natural resources is in the common interest of, and beneficial to, the entire society.

\section{Acknowledgements}

The authors thank the state research support foundation, Amazon Foundation for Support to Studies and Research of Pará - FAPESPA, for awarding a doctoral scholarship, since this study expanded on data from a doctoral thesis in Agronomy at the Federal Rural University of Amazonia - UFRA.

\section{References}

ADAMI, M.; GOMES, A. R.; COUTINHO, A. C.; ESQUERDO, J. C. D. M.; VENTURIERI, A. Dinâmica do uso e cobertura da terra no estado do Pará entre os anos de 2008 a 2012. In: SIMPÓSIO BRASILEIRO DE SENSORIAMENTO REMOTO, 17., 2015, João Pessoa. Anais... João Pessoa: INPE, 2015. p. 7028-7035. Disponível em: <http://www.ppgca.ufpa.br/arquivos/ repositorio/TEXTODOWN/Din \%C3\%A2mica \% $20 \mathrm{do} \% 20$ uso $\% 20 \mathrm{e} \% 20$ cobertura $\% 20 \mathrm{da} \% 20$ terra $\% 20$ no $\% 20$ estado\%20do\%20Par\%C3\%A1.pdf $>$. Acesso em: 22 jan. 2016.

AGROPALMA. História. Belém: [s.n.], 2014. Disponível em: $\quad<$ http://www.agropalma.com.br/historia.asp $>$. Acesso em: 5 ago. 2014.

ADVOCACIA GERAL DA UNIÃO - AGU. Nota técnica $\mathrm{N}^{\circ} \quad 01 / 2013 / \mathrm{PFE} / \mathrm{INCRA} / \mathrm{PGF} / \mathrm{AGU}$. Novo Código Florestal-Lei no 12.651/2012. Implicações sobre atuação do Incra. Análise Jurídica. Orientações Gerais. Brasília: AGU, 2013. Disponível em: <www.agu.gov.br/ page/download/index/id/16515838>. Acesso em: 22 jan. 2016.

ALARCON, G. G.; AYANU, Y.; FANTINI, A. C.; FARLEY, J.; SCHMITT FILHO, A.; KOELLNER, $\mathrm{T}$. Weakening the Brazilian legislation for forest conservation has severe impacts for ecosystem services in the Atlantic Southern Forest. Land Use Policy, Adelaide, v. 47, p. 1-11, 2015.

ALMEIDA, A. S. de; VIEIRA, I. C. G. Conflitos no uso da terra em áreas de preservação permanente em um polo de produção de biodiesel no estado do Pará. Ambiente \& Água, Taubaté, v. 9, n. 3, p. 476-487, 2014. 
AMARAL, M. V. F.; SOUZA, A. L. de; SOARES, V. P.; SOARES, C. P. B.; LEITE, H. G.; MARTINS, S. V.; FERNANDES FILHO, E. I.; LANA, J. M. de. Avaliação e comparação de métodos de classificação de imagens de satélite para o mapeamento de estádios de sucessão florestal. Revista Árvore, Viçosa, MG, v. 33, n. 3, p. 575$582,2009$.

AULICINO, L. C. M.; RUDORFF, B. F. T.; MOREIRA, M. A.; MEDEIROS, J. S.; SIMI JÚNIOR, R. Subsídios para o manejo sustentável da bacia hidrográfica do rio Una através do uso de técnicas de geoprocessamento e sensoriamento remoto. In: SIMPÓSIO LATINO AMERICANO DE PERCEPCIÓN REMOTA, 9., 2000, Puerto Iguazu. Anais... Lujan: SELPER, 2000. p. 899908.

BARBER, C. P.; COCHRANE, M. A.; SOUZA JÚNIOR, C. M.; LAURANCE, W. F. Roads, deforestation, and the mitigating effect of protected areas in the Amazon. Biological Conservation, Essex, v. 177, p. 203-209, 2014.

BARBOSA JÚNIOR, J. S. Análise de áreas de preservação permanente, através de geoprocessamento e sensoriamento remoto no município de Bonito - Pará. 2012. Trabalho de Conclusão de Curso (Graduação em Geografia) - Faculdade de Geografia e Cartografia, Universidade Federal do Pará, Belém.

BECKER, B. K. Recuperação de áreas desflorestadas da Amazônia: será pertinente o cultivo da palma de óleo (Dendê)? Confins [on line], Marseille, n. 10, 2010. Disponível em: <http://confins.revues.org/6609 \#text>. Acesso em: 9 abr. 2013.

BLACKBRIDGE. RapidEye, satellite imagery product specifications. Berlim: [s.n.], 2015. Available at: $<$ http://blackbridge.com/rapideye/upload/RE_Product Specifications_ENG.pdf $>$. Accessed at: 6 jul. 2015.

BRASIL. Código florestal 4.771, de 15 de setembro de 1965. Brasília: Casa Civil, 1965. Disponível em: <http:// www.planalto.gov.br/ccivil_03/leis/L4771.htm>. Acesso em: 10 mar. 2014.

Código florestal 12.651 , de 25 de maio de 2012. Brasília: Casa Civil, 2012. Disponível em: $<$ http:// www.planalto.gov.br/ccivil_03/_ato2011-2014/2012/lei/ 112651.htm>. Acesso em: 10 mar. 2014.

CONSELHO NACIONAL DO MEIO AMBIENTE CONAMA. Resolução no 303, de 20 de março de 2002. Dispõe sobre parâmetros, definições e limites de Áreas de Preservação Permanente. Diário Oficial [da] República Federativa do Brasil, CONAMA, Brasília, DF, 13 maio. 2002. Seção 1, p. 68.

Resolução $n^{\circ}$ 302, de 20 de março de 2002. Dispõe sobre parâmetros, definições e limites de Áreas de Preservação Permanente de reservatórios artificiais e o regime de uso do entorno. Diário Oficial [da] República Federativa do Brasil. CONAMA, Brasília, DF, 13 maio. 2002. Seção 1, p. 67-68.

CARVALHO, T. M.; BAYER, M. Utilização dos produtos da Shuttle Radar Topography Mission (SRTM) no mapeamento geomorfológico do estado de Goiás. Revista Brasileira de Geomorfologia, São Paulo, v. 9, n. 1, p. 35-42, 2008.

CATELANI, C. S.; BATISTA, G. T. Mapeamento das áreas de preservação permanente (APP) do município de Santo Antônio do Pinhal, SP: um subsídio à preservação ambiental. Ambi-Agua, Taubaté, v. 2, n. 1, p. 30-43, 2007.

CENTRO GESTOR E OPERACIONAL DO SISTEMA DE PROTEÇÃO DA AMAZÔNIA - CENSIPAM. Projeto do Ministério da Defesa mapeia mais de 70\% do vazio cartográfico da Amazônia. Brasília: CENSIPAM, 2016. Disponível em: <http://www.defesa.gov.br/ noticias/18820-projeto-do-ministerio-da-defesa-mapeiamais-de-70-do-vazio-cartografico-da-amazonia>. Acesso em: 13 fev. 2017.

EMPRESA BRASILEIRA DE PESQUISA AGROPECUÁRIA - EMBRAPA Solos. Centro Nacional de Pesquisa de Solos. Zoneamento Agroecológico do dendezeiro para as áreas desmatadas da Amazônia Legal. Rio de Janeiro: EMBRAPA, 2010.

ENGESAT: SPOT 5. Ficha técnica. Curitiba, 2002. Disponível em: <http://www.croce.ggf.br/SR/SR1/ SPOT\%205.htm>. Acesso em: 25 abr. 2015.

FELFILI, J. M.; SILVA JÚNIOR, M. C. da; SERVILHA, A. C.; FAGG, C. W.; WALTER, B. M. T.; NOGUEIRA, P. E.; REZENDE, A. V. Diversity, floristic and structural patterns of Cerrado vegetation in central Brazil. Plant Ecology, Dordrecht, v. 175, n. 1, p. 37-46, 2004.

FEARNSIDE, P. M. Consequências do desmatamento da Amazônia. Scientific American Brasil Especial:Brasil a Maior Biodiversidade do Mundo, São Paulo, n. 39, p. 5459, 2010.

Desmatamento na Amazônia: dinâmica, impactos e controle. Acta Amazônica, Manaus, v. 36, n. 3, p. 395-400, 2006.

Land-tenure issues as factor in environmental destruction in brazilian Amazonia: the case of Southern Pará. World Development, New York, v. 29, n. 8, p. 13611372, 2001.

FERREIRA, L. V. Identificação de áreas prioritárias para a conservação da biodiversidade por meio da representatividade das unidades de conservação e tipos de vegetação nas ecorregiões da Amazônia brasileira. 
In: CAPOBIANCO, J. P. R. (Ed.). Biodiversidade na Amazônia Brasileira: avaliação e ações prioritárias para a conservação, uso sustentável e repartição de benefícios. São Paulo: Instituto Socioambiental, 2001. p. 268-286.

FERREIRA, L. V.; VENTINCINQUE, E.; ALMEIDA, S. O desmatamento na Amazônia e a importância das áreas protegidas. Estudos Avançados, São Paulo, v. 19, n. 53, p. 157-166, 2005. Disponível em: <http:// www.scielo.br/scielo.php?script=sci_arttext\&pid $=$ S0103-40142005000100010>. Acesso em: 19 ago. 2016.

GONÇALVES, M. L.; ANDRADE NETTO, M. L. de; ZULLO JUNIOR, J.; COSTA, J. A. F. Classificação não-supervisionada de imagens de sensores remotos utilizando redes neurais auto organizáveis e métodos de agrupamento hierárquicos. Revista Brasileira de Cartografia, Rio de Janeiro, v. 1, n. 60/01, p. 17-29, 2008.

GURGEL, R. S.; CARVALHO JÚNIOR, O. A.; GOMES, R. A. T.; GUIMARÃES, R. F.; MARTINS, E. de S. Identificação das áreas vulneráveis à erosão a partir do emprego da EUPS - equação universal de perdas de solo no município de Riachão da Neves - BA. Geografia Ensino \& Pesquisa, Santa Maria, v. 15, n. 1, p. 93-112, 2011.

. Relação entre a evolução do uso da terra com as unidades geomorfológicas no município de Riachão das Neves (BA). GeoTextos, Salvador, v. 9, n. 1, p. 177-201, 2013.

HOMMA, A. K. O.; FURLAN JÚNIOR, J.; CARVALHO, R. A.; FERREIRA, A. Bases para uma política de desenvolvimento da cultura do dendê na Amazônia. In: VIEGAS, I. J. M.; MULLER, A. A. (Org.). A cultura do dendezeiro na Amazônia Brasileira. Belém: Embrapa Amazônia Ocidental, 2000. p. 11-30.

HOMMA, A. K. O.; VIEIRA, I. C. G. Colóquio sobre dendezeiro: prioridade de pesquisas econômicas, sociais e ambientais na amazônia. Amazônia: Ciência \& Desenvolvimento, Belém, v. 8, n. 15, p. 79-90, 2012.

INSTITUTO DE DESENVOLVIMENTO ECONÔMICO, SOCIAL E AMBIENTAL DO PARÁ -IDESP. Estatística Municipal: Tailândia. 2014. Disponível em: <http://www.idesp.pa.gov.br/pdf/ estatistica Municipal/pdf/Tailandia.pdf $>$. Acesso em: 29 mar. 2014.

INSTITUTO DO HOMEM E MEIO AMBIENTE DA AMAZÔNIA - IMAZON. Desmatamento e degradação florestal em Tailândia - Pará 2000 - 2013, 2014. Belém: IMAZON, 2014. Disponível em: http://imazon.org.br/ PDFimazon/Portugues/outros/01_Folder_Tailandia_ web.pdf $>$. Acesso em: 17 jun. 2015.
INSTITUTO BRASILEIRO DE GEOGRAFIA E ESTATÍSTICA - IBGE. Cidades. Rio de Janeiro: IBGE, 2015. Disponível em:<http://www.cidades.ibge.gov.br/ xtras/perfil.php?lang $=\&$ codmun $=150470>$. Acesso em: 8 abr. 2015.

Cidades. Tailândia, histórico. Rio de Janeiro: IBGE, 2015. Disponível em: <http://www.cidades.ibge. gov.br/painel/historico.php?codmun=150795>. Acesso em: 10 mar. 2017.

INSTITUTO DE PESQUISA AMBIENTAL DA AMAZÔNIA - IPAM. Desmatamento em foco. Belém: IPAM, 2012. Disponível em: <http://www.ipam.org.br/ saiba-mais/Desmatamento-em-Foco/>. Acesso em: 13 maio 2015.

INSTITUTO NACIONAL DE PESQUISAS ESPACIAIS - INPE. Monitoramento da Floresta Amazônica Brasileira por Satélite. São José dos Campos: PRODES, 2014. Disponível em: <http://www.obt.inpe.br/ prodes/ index.php>. Acesso em: 4 fev. 2014.

LEES, A. C.; VIEIRA, I. C. G. Oil-palm concerns in Brazilian Amazon. Nature, London, v. 497, p. 188-188, 2013. Disponível em: <http://www.nature.com/nature/ journal/v497/n7448/full/497188c.html>. Acesso em 13 fev. 2017.

LIMA, A. L. Pesquisas buscam a causa do amarelecimento fatal do dendezeiro. Agroenergia em Revista, Brasília, v. 2, n. 2, p. 17-17, maio, 2011. Disponível em: <https:// issuu.com/embrapa/docs/revista_ agroenergia_ed2 $>$. Acesso em: 1 ago. 2016.

LOUREIRO, V. R.; PINTO, J. N. A. A questão fundiária na Amazônia. Estudos Avançados, São Paulo, v.19, n. 54, p. 77-98.

MENESES, P. R.; SANO, E. E. Classificação de pixel a pixel de imagens. In: MENESES, P. R.; ALMEIDA de T. (Org.). Processamento de imagens de sensoriamento remoto. Brasília: UnB/CNPq, 2012. p. 201-208.

MINISTÉRIO DO MEIO AMBIENTE - MMA. Imagem de satélite RapidEye. Brasília: MMA, 2012. Disponível em: <http://www.geocatalogomma.com.br/>. Acesso em: 12 abr. 2013.

NAHUM, J. S.; MALCHER, A. T. Dinâmicas territoriais do espaço agrário na Amazônia: a dendeicultura na microrregião de Tomé-Açu (PA). Confins[on line], Marseille, n. 16 2012. Disponível em: <http://confins. revues.org/7947?lang=pt $>$. Acesso em: 28 out. 2015.

NEPSTAD, D.; CARVALHO, G.; BARROS, A. C.; ALENCAR, A.; CAPOBIANCO, J. B.; BISHOP, J.; MOUTINHO, P.; LEFEBVRE, P.; SILVA, U. L. Road paving, fire regime feedbacks, and the future of Amazon 
Forests. Forest Ecology and Management, Amsterdã, v. 154 , p. 395-407, 2001.

OLIVEIRA, S. N. de. Análise das mudanças espaciais e temporais nos padrões de paisagem na Região do Oeste da Bahia sobre a formação do Grupo Urucuia (1988-2011) e suas implicações para a conservação do Cerrado. 2015a. Tese (Doutorado em Geografia) Universidade de Brasília, Brasília.

OLIVEIRA, G. B. O novo código florestal e a reserva legal do Cerrado. 2015b. Dissertação. (Mestrado em Ecologia) - Universidade de Brasília, Brasília.

PENTEADO, J. R. A operação arco de fogo em Tailândia - Pará. 2010. Trabalho de Conclusão de Curso (Graduação em Comunicação social e jornalismo habilitação em Jornalismo) - Faculdade de Arquitetura, Artes e Comunicação, Universidade Estadual Paulista Júlio Mesquita Filho, São Paulo.

PRATES, R. C.; BACHA, C. J. C. Os processos de desenvolvimento e desmatamento da Amazônia. Economia e Sociedade, Campinas, v. 20, n. 3, p. 601636, 2011.

REIS, L. C.; REIS, T. E. S.; SAAB, O. J. G. A. Diagnóstico das áreas de preservação permanente das microbacias hidrográficas do município de Bandeirantes - Paraná. Semina: Ciências Agrárias, Londrina, v. 30, n. 3, p. 527-536, 2009.

RODRIGUES, T. E.; SILVA, J. M. L.; SILVA, B. N. R.; VALENTE, M. A.; GAMA, J. R. N. F.; SANTOS, E. S.; ROLIM, P. A. M.; PONTE, F. C. Caracterização e classificação dos solos do município de Tailândia, estado do Pará. Belém: Embrapa Amazônia Oriental, 2005. 55 p.

SARAIVA, A. G. S.; SOUSA, R. F. de; MENESES, L. F. de. Análise multitemporal do processo de desertificação do município de Boa Vista - PB utilizando dados orbitais. In: SIMPÓSIO BRASILEIRO DE CIÊNCIAS GEODÉSICAS E TECNOLOGIA DA INFORMAÇÃO, 3., 2010, Recife. Anais... Recife: Universidade Federal de Pernambuco, 2010. p. 1-8.

SOARES FILHO, B.; RAJÃO, R.; MACEDO, M.; CARNEIRO, A.; COSTA, W.; COE, M.; RODRIGUES, H.; ALENCAR, A. Cracking Brazil's forest code. Science, Washington, v. 344, n. 6.182 p. 363-364, 2014.

SOCIEDADE BRASILEIRA PARA O PROGRESSO DA CIÊNCIA - SBPC; ACADEMIA BRASILEIRA DE CIÊNCIAS - ABC. O código florestal e a ciência: contribuições para o diálogo. 2. ed. São Paulo: SBPC, 2012.
SOUZA, K. R.; VIEIRA, T. G. C.; ALVES, H. M. R.; VOLPATO, M. L.; ANJOS. L. A. P. dos; SOUZA, C. G.; ANDRADE, L. N. Classificação automática de imagem do satélite RapidEye para o mapeamento de áreas cafeeiras em Carmo de Minas, MG. In: SIMPÓSIO DE PESQUISA DOS CAFÉS DO BRASIL, 7., 2011, Araxá. Anais... Araxá: Consórcio Pesquisa Café, 2011. Disponível em: <http://www.sbicafe.ufv.br/bitstream/ handle/10820/3870/76.pdf? sequence $=2>$. Acesso em: 17 maio 2015.

SOUZA JÚNIOR, C.; AMARAL, P.; SALES, M.; SALOMÃO, R.; OLIVEIRA JÚNIOR, L.; BATISTA, W.; MARTINS, J. Base de informações geográficas para gestão ambiental municipal na Amazônia. Revista Brasileira de Cartografia, Rio de Janeiro, v. 3, n. 65, p. 591-603, 2013.

STRAHLER, A. N. Physical geography. New York: JohnWilley \& Sons, 1951. 442 p.

TAGLIALEGNA, G. H. F. Reforma do código florestal: busca do equilíbrio entre a agricultura sustentável e a preservação do meio ambiente. Brasília: [s.n.], 2011. p. 1-13. Disponível em: <http://www12.senado.gov. br/publicacoes/estudos-legislativos/tipos-de-estudos/ outras-publicacoes/agenda-legislativa/capitulo-3reforma-do-codigo-florestal-busca-do-equilibrio-entrea-agricultura-sustentavel-e-a-preservacao-do-meioambiente>. Acesso em: 10 jan. 2016.

TAVARES, M. G. da C. A Amazônia brasileira: formação histórico-territorial e perspectiva para o século XXI. Espaço e Tempo, São Paulo, v. 29, p. 107-121, 2011. Número Especial.

VASCONCELOS, C. H.; NOVO, E. M. L.de M. Mapeamento de uso e cobertura da terra a partir da segmentação e classificação de imagens - fração solo, sombra e vegetação derivadas de modelo linear de mistura aplicado a dados do sensor TM/Landsat5, na região do reservatório de Tucuruí-PA. Acta Amazônica, Manaus, v. 34, n. 3, p. 487-493, 2004.

VIEIRA, I. C. G.; TOLEDO, P. M. de; SILVA, J. M. C. da; HORÁCIO, H. Deforestation and threats to the biodiversity of Amazonia. Brazilian Journal of Biology, São Carlos, v. 68, n. 4, p. 631-637, 2008.

WATRIN, O. S.; MACIEL, M. N. M.; THALÊS, M. C. Análise espaço-temporal do uso da terra em microbacias hidrográficas no município de Paragominas, Estado do Pará. In: SIMPÓSIO BRASILEIRO DE SENSORIAMENTOREMOTO, 13., 2007, Florianópolis. Anais... Florianópolis: INPE, 2007. p. 7019-7026. Disponível em: <http://ainfo.cnptia.embrapa.br/digital/ bitstream/item/94119/1/7019-7026.pdf>. Acesso em: 10 jan. 2016. 
